\title{
LEGITIMACY FROM ABOVE: \\ The Partisan Foundations of Support for the Political System in Democracies
}

\author{
Christopher J. Anderson
}

Department of Government, Cornell University, Ithaca, NY, USA

\author{
Aida Just \\ Department of Political Science, Bilkent University, Bilkent, Ankara, Turkey
}

\begin{abstract}
We investigate the partisan foundations of political legitimacy. We argue that the goals parties pursue shape their supporters' views about the political system via the messages they communicate about the desirability of the political system. Combining public opinion survey data collected in 15 democracies with data on the goal orientations and policy positions of 116 political parties, we find that office-seeking parties take more positive positions toward the status quo of the political regime than policy-seeking parties. Moreover, our results confirm that these positions have consequences. Specifically, supporters of parties with more positive positions toward the system report systematically higher levels of support than supporters of parties that communicate more negative views. Taken together, these findings suggest that political parties play an active role in shaping citizens' views of the political system and that office-seeking parties in particular mobilize consent among citizens in contemporary democracies.
\end{abstract}


At least since the Weimar Republic's descent into fascism, scholars have assumed that low levels of citizen support can pose serious problems for democracies (Lipset, 1959; Powell, 1982, 1986). ${ }^{1}$ As a result, researchers have devoted considerable energy to understanding beliefs about the political system, producing extensive literatures on system support - also variously referred to as political trust, confidence, legitimacy beliefs, and consent. Based on Eastonian notions of the importance of system outputs, as well as ideas about procedural and outcome fairness in the production of those outputs, scholars have come to the conclusion that these attitudes are shaped by what political systems are and do - their institutions, processes, and performance - and how people come to form beliefs about these - that is, individuals' experiences with, and their perceptions and beliefs about, the system. As a consequence, people are said to extend greater legitimacy to political systems that produce superior outcomes (economic, political, and the like), and that do so fairly in citizens' eyes (Tyler, 1990).

Fundamentally, such explanations of political consent are based on a bottom-up model of legitimacy rooted in a principal-agent conception of democracy, where citizens as principals evaluate the performance of state institutions and choose to bestow legitimacy on them or withhold it. The literature on system support that has grown up around this conception is broad and deep, and it has focused mostly on whether various kinds of performance indicators - such as the economy or political outcomes - affect people's views of the political system. Typically missing from such accounts of legitimacy, however, are explanations that involve a degree of agency on the part of political elites rather than citizens. This is a curious and critical omission, given the 
importance that students of democratic stability have frequently assigned to the actions of political elites (e.g., Bunce, 2003; Geddes, 1999; Przeworski, 2005; Weingast, 1997).

This paper seeks to bring elites back into the study of system support through the door of political parties. While citizens frequently take a dim view of partisan politics and how it affects the functioning of democracy (Hibbing and Theiss-Morse, 1995), few political scientists would dispute that political parties continue to play a crucial role in organizing democratic politics. In fact, democracy may be indeed unworkable (Aldrich, 1995), if not unthinkable, save in terms of parties (Schattschneider, 1942). In this study, we examine how the central actors in democratic politics - political parties - contribute to political legitimacy and the ways in which political parties and partisanship jointly shape people's views about the political system. We argue that the goals parties pursue shape their supporters' views via the messages they communicate about the desirability of the political system. Thus, parties signal to their supporters their position on the functioning of the political system, and partisans are motivated to adopt their party's position on whether the political system is worth their support.

These arguments have important normative implications for how we view the underpinnings of democratic legitimacy. Instead of bubbling up from below through people's sovereign evaluations of the political system's functioning, our argument implies the active mobilization of partisan consent from above. In this way, political parties and the state on which they depend for resources and which they help guide are actively capable of mobilizing biases (or to use a more neutral term, heterogeneity) in citizens' views (Schattschneider, 1960; see also Sniderman and Hagendoorn, 2007). In fact, some parties are motivated to express support for the existing order to promote their 
own organizational success. This also implies that legitimacy is more partisan and more elite driven than is often portrayed in the literature.

To test our arguments, we combine and analyze mass survey data alongside data on parties' goal orientations and policy positions in broad set of established democracies. Our results show that parties whose primary goal is to win office take more positive positions with regard to the status quo of the political regime. Moreover, we find that partisans of parties with more positive positions toward the system report higher levels of political support than those of parties that take more negative positions. These findings suggest that political parties play an active role in shaping citizens' views of the political system and office-seeking parties in particular foster regime support among sizable segments of democratic electorates by communicating more positive opinions about the political system to their partisans than policy-seeking parties doß.

\section{Explaining System Support}

Over the years, students of political trust and system support have documented significant variation - across countries and over time - in citizens' views toward democratic governance (Fuchs and Klingemann,1995; Klingemann, 1999). Speaking broadly, they have sought to explain this variation by focusing on how system performance and political context matter for people's opinions about the political system. For example, citizens in countries whose economies perform better also typically have more positive views about the political system (e.g, Clarke, Dutt, and Kornberg, 1993). Furthermore, studies have found that political systems whose characteristics enhance procedural and outcome fairness, and that do a better job representing citizens' views in 
the policy process, engender more positive attitudes about government among citizens (Miller and Listhaug, 1999). Specifically, people support institutions that are fair, transparent in their policy-making, as well as open to competing views (Tyler, 1990; Levi, 1997; Dalton, 1999; Levi and Stokes, 2000). Further, individuals in systems with more durable and less corrupt governments and governments that respect people's political rights are more supportive of the existing political arrangements (Harmel and Robertson, 1986; Mishler and Rose, 1997, 2001; Anderson and Tverdova, 2003).

Taken together, these findings paint a rich picture of how political institutions and the consequences they produce affect people's legitimacy beliefs. Their contribution to how we think about legitimacy is particularly notable for providing explanations for cross-national and cross-temporal differences in levels of system support. This focus on cross-national differences has created an empirical and theoretical imbalance in the literature on political support, however. At the empirical level, what remain underexplored (and virtually ignored) are the high levels of variation within countries among similarly situated citizens. While some of the relatively static demographic or socio-economic characteristics of individuals - age, education, income, class, and gender - are consistently correlated with political support, much of its within-country variation remains unexplained (see, for instance, Newton, 1999; Newton and Norris, 2000; Orren, 1997).

The focus on cross-national differences in macro-political contexts as explanations of public support has produced a theoretical imbalance as well. Existing literature takes either a very macro- (or system-) focused view of why legitimacy varies, or it searches for the causes of this variation in individual citizens themselves. We argue 
that missing from existing explanations is the connective tissue of political parties and partisanship - politics, so to speak. In particular, to date the literature on political legitimacy has paid limited attention to the role parties play in actively shaping citizens' views of the political system. Findings from empirical studies that have considered parties indicate that the availability of opportunities to express discontent - for example, because of the existence of minor protest parties - can enhance system support (Miller and Listhaug, 1990). Similarly, citizens in countries with moderate multi-party systems as well as those with more proportional electoral rules exhibit higher levels of confidence in the functioning of political institutions (Norris, 1999).

Yet, as is the case with existing scholarship on legitimacy generally, these explanations focus squarely on differences across political systems rather than on variation within systems. Below, we argue that a more comprehensive explanation of the role that political parties play requires a systematic examination of differences in the party-voter connection within countries as well, and that partisan attachments constitute the crucial link between parties, voters, and legitimacy beliefs.

\section{The Missing Link: Parties and Partisans}

Our model of citizen attitudes toward the political system involves two important elements - political parties and their supporters - that are connected via partisanship. First, we argue that parties vary in the goals they pursue, and this leads them to take different positions about the desirability of existing political institutions. Second, we argue that party identification is the channel that allows parties to effectively communicate their positions to partisan supporters. Because parties differ in their 
positions regarding the efficacy and desirability of existing political institutions and arrangements, and communicate these to their supporters, we expect significant heterogeneity in partisans' views of the political system within countries.

\section{Partisanship}

Since the behavioral revolution in political science, partisanship (or partisan attachment, partisan identification) has been a fundamental organizing concept for understanding political behavior. More specifically, it is a major factor in shaping people's attitudes about politics and, subsequently, their behavior. Following The American Voter, party identification typically has been conceptualized as an individual's enduring affective attachment to a political party that is the product of early socialization experiences (Campbell et al., 1960, 1966; Hess and Torney, 1967; Franklin and Jackson, 1983; Franklin, 1984). ${ }^{2}$ As a kind of social identity, this conceptualization is rooted in reference group theory and reflects the idea that individuals often define aspects of the self in terms of secondary groups in society, including political parties (Campbell et al.,1960, Ch 6; Green, Palmquist, and Schickler, 2002).

Because partisanship is assumed to reflect a psychological attachment to a political party, the conceptualization of individuals as partisans does not require their official membership in a party or other behavioral outcomes, such as voting for a particular party, although these may all be highly correlated with one another (Miller and Shanks, 1996). Critical for our purposes, however, is the idea that partisanship, once acquired, subsequently shapes how new political information is interpreted. It thus acts as 
a so-called "perceptual screen through which the individual tends to see what is favorable to his partisan orientation" (Campbell et al., 1960: 133).

Given the central role political parties play in modern democracies, we expect partisans to be motivated to accept the political status quo, including the political regime (its institutions and processes). Compared to non-partisans, partisans should therefore express higher levels of support for the role of political parties in a democracy, the party system they constitute, and the political order in which they are embedded (Holmberg, 2003; Miller and Listhaug, 1990). Put simply, partisans like parties, and they care enough about politics to maintain an expressed attachment to them and the political system in which they operate (cf. Paskeviciute, 2009).

A number of scholars assume that this connection between partisanship and system support exists, and that it is of direct relevance to, and in fact an indicator of, the health of democratic political systems (Dalton, 1996, 1999; Holmberg, 2003; Torcal, Gunther, and Montero, 2002; Miller and Shanks, 1996; Budge, Crewe, and Farlie, 1976). In fact, because of the strong relationship between party identification and support for the political system, some worry that weakening partisan attachments might erode people's faith in democratic politics. The oft-decried decline in partisan attachments across Western democracies, so the argument goes, could turn out to be contagious and herald a disengagement from politics amongst voters and a decline in support for party-based democracy more generally (Dalton, 1999: 66; see also Holmberg, 2003). Similarly, the lack of strong partisan attachments in newly democratic states is seen as providing only a weak foundation for system support and regime stability (Dalton and Weldon, 2007). 


\section{Party Goals and Partisan Support for the Political System}

Viewed from the traditional partisanship perspective, partisan attachments should lead to higher levels of political support generally, regardless of the specific party voters identify with. After all, even parties outside of the political mainstream signal some allegiance to the rules of the democratic game, due to the very fact that they organize themselves as parties and contest elections. However, we argue that such a view oversimplifies reality by overlooking the fact that partisanship can have a variety of effects on how people view the political system. Specifically, we posit that parties differ significantly in the positions they take with regard to the political system, and that partisans are motivated to adopt these positions as their own. Not all parties are equally fond of the political status quo, and their supporters' views reflect this variation as a result.

We theorize that this variation in parties' positions regarding the desirability and efficacy of existing institutional arrangements and procedures stems from the kinds of goals they pursue - or what has come to be known as parties' goal orientations. Parties typically pursue a mix of goals, most prominently among them the pursuit of legislative and government office as well as a set of policy goals. According to Strøm's (1990) behavioral theory of competitive parties, party leaders often find themselves in a position of having to trade off one goal - say, office - for the other - say, policy. This does not assume that they inherently value one more than the other, but it does mean that parties often cannot maximize on both dimensions (Strøm, 1990; Müller and Strøm, 1999; Erikson and Romero, 1990; Adams, 2001). ${ }^{3}$ Depending on how party leaders resolve this 
trade-off, parties can be categorized as pursuing primarily policy goals (policy-seeking parties), winning and maintaining office (office-seeking parties), or a mix of the two.

We argue that these goal orientations affect parties' positions on the existing political structure in the country. Because office- seeking parties are less encumbered by party activists' policy preferences and are therefore freer to maximize (re-)election (Strøm, 1990), they also are more likely to be electorally competitive, actually get elected to office, and implement their preferred policies. In fact, because office-seeking parties are more likely to become parties in parliament and government, they are also more likely to write the rules of the game and be in charge of enforcing them than parties outside of government or parliament. As a consequence, they are also more likely to benefit from the status quo of a political system.

Because they are the parties most deeply embedded in the state structure and responsible for its design and administration, we expect office-seeking parties to take more positive positions toward the existing system than policy-seeking parties. ${ }^{4}$ Although Laver and Hunt's (1992) expert survey of party goals does not identify any parties as purely office-seeking to the exclusion of all other goals, examples of parties that give high priority to office over policy include the Center Democrats and Social Democrats in Denmark, the Independence Party in Iceland, and the Liberals as well as the Progressive Conservatives in Canada.

This should differ starkly from policy-seeking parties. According to Strøm's schema, these parties are more dependent on party membership as a resource, less likely to compromise their views and, as a consequence, less likely to gain elective office or enter governments. In addition, the very fact that a party is driven primarily by policy 
considerations rather than the desire to win office implies that holding the reins of the status quo political structure is less important to them (and their members) than achieving political change, including perhaps institutional changes that would make it easier for such parties to be successful. Good examples of policy seeking parties are the (now defunct) Vlaams Blok in Belgium ${ }^{5}$ and the Reformed Political Party in the Netherlands. This does not imply that only policy-seeking parties ever propose institutional changes or that office-seeking parties never do - a good example of the latter is Britain's Labour Party and its push for devolution - but it does imply that there is a general and longstanding tendency for office-seeking parties to be more supportive of the existing political system than parties that primarily pursue goals other than office.

The expectation that office oriented parties seek to reinforce the political status quo and thus are more likely to stake out positive positions about the system than policy seeking parties is only the first part of our story, however. The important second part is our contention that parties' positions about the state and existing institutions will be reflected among party identifiers. Specifically, because the functioning of the political system is complex and often arcane, and because voters are known to be cognitive misers, partisanship is the channel by which individuals are motivated to adopt the political orientations of a party. As a result, the positions parties take about the political system signal to partisans how and how well the system works. In most basic terms, if a political party takes a more positive position toward the system, its supporters will also express more positive attitudes toward that system. Conversely, political parties that take negative positions about the political regime in their country are also more likely to produce more cynicism among their partisans. In this way, parties' positions (and 
messages) about the political system are the mechanism that links parties' organizational goals and their partisans' views of the desirability of the political regime.

In short, we argue that partisanship plays a crucial role in linking political parties and citizens in shaping their legitimacy beliefs, and hypothesize two mechanisms by which party identification influences people's attitudes towards the political system: 1) the traditional view, according to which partisanship should increase people's support for the political system regardless of the opinions parties express about the status quo of the political system, and 2) the party persuasion view, according to which positive party positions about the system should contribute positively to the legitimacy beliefs of their partisans. ${ }^{6}$

Our argument implies that parties' positions are exogenous to their supporters' views: that is, the causal arrow is expected to run from parties' messages to partisans' views, rather than the reverse. We cannot completely rule out that some individuals may develop a partisan attachment to parties whose positions on the political system they agree with. However, we believe that our argument can be justified on a number of grounds. First, our expectations about the role of partisanship as a mover of attitudes about the political system are plausible and consistent with considerable amounts of research into the role of partisanship in shaping political behavior. Among these, the Michigan-based conception of party identification as an "unmoved mover" supports this interpretation: most citizens develop partisan attachments early in life, and these attachments are strongly resistant to change (Campbell et al., 1960; Miller and Shanks, 1996; see also Green, Palmquist, and Schickler, 2002). And while we acknowledge that the stability of party identification is sometimes less than perfect, we also wish to note 
that partisanship is a robust mover of people's opinions regardless of its stability at the individual level, ${ }^{7}$ and that research on panel data consistently reveal partisanship to be causally prior to attitudes. ${ }^{8}$ Taken together, existing studies suggest that we are on safe grounds in expecting that partisan attachment increases the odds that voters rely on the party positions as a guide for political orientations, and that strong partisanship augments the persuasive power parties have for their supporters (Jacoby, 1988; see also Zaller, 1992). As a consequence, our model of party positions, partisanship, and legitimacy beliefs implies a set of variable effects of partisanship on support depending on, and set in motion by, parties' positions on the legitimacy and desirability of the existing democratic regime.

\section{Data and Measures}

To test our hypotheses about the potential heterogeneity in partisans' views of the political system within countries, we combined and analyzed data collected at the level of individuals and political parties. Specifically, we combine survey data collected as part of the Comparative Study of Electoral Systems (CSES) project (Module 1, 1996-2000) to measure partisanship and system support at the level of citizens with data on political parties from Laver and Hunt's (1992) expert surveys and the Comparative Manifestos Project (CMP) (Klingemann et al., 2006) to measure parties' goal orientations and their positions about the political system. The relevant survey and party indicators were available for 116 political parties in a broad set of established democracies (Australia, Belgium, Canada, Denmark, Germany, Iceland, Israel, the Netherlands, New Zealand, Norway, Portugal, Spain, Sweden, Great Britain, and the United States). ${ }^{9}$ The key 
individual level variables are partisanship and system support, while the key party-level variables are party goal orientations and parties' positions about the political system.

\section{Voters}

\section{System Support}

We use two measures from the CSES surveys to gauge citizen support for the political system - satisfaction with democracy and external efficacy (attitudes about system responsiveness). Widely used, both tap into citizen evaluations of the performance of the political system at the level of the political regime (cf. Norris, 1999). Satisfaction with democracy is an indicator of system support measured at a low level of generalization (Fuchs, Guidorossi, and Svenson, 1995: 330; Anderson and Guillory, 1997). While not without critics, it is commonly acknowledged to measure support for regime performance (Klingemann, 1999), as it focuses on people's responses to the actual process of democratic governance and their attitudes toward a country's "constitutional reality" rather than democracy as an ideal (Fuchs, Guidorossi, and Svenson, 1995: 328; Anderson et al., 2005: 41; Linde and Ekman, 2003). The relevant survey measure asked citizens whether they are very satisfied, fairly satisfied, not very satisfied, or not at all satisfied with the way democracy works in their country. The variable ranges from 0 to 3 , with higher values indicating a more satisfied response.

Political efficacy refers to "the feeling that individual political action does have, or can have, an impact upon the political process ... the feeling that political and social change is possible, and that the individual citizen can play a part in bringing about this change" (Campbell, Gurin, and Miller, 1954: 187). Research distinguishes between 
internal and external efficacy and defines the former as an individual's sense that he or she can personally affect the political process and the latter as beliefs about the responsiveness of the political system to the electorate (Lane, 1959; Balch, 1974; Miller and Listhaug, 1990; Anderson et al., 2005: 42). External efficacy is particularly useful for our purposes because it measures citizens' perceptions of the system's performance on a normatively desirable dimension (responsiveness to citizen demands). Two survey items of whether politicians know and care what ordinary people think were used to construct this variable. ${ }^{10}$ The resulting indicator ranges from 0 to 8 , with higher values on this index indicating a greater sense of external efficacy (see appendix for details). ${ }^{11}$

\section{Party Identification}

Students of electoral politics have long debated the conceptualization and measurement of party identification (Campbell et al., 1960; Budge, Crewe, and Farlie, 1976; Fiorina, 1981). In a comparative context, the focus of contention has been whether the construct is applicable in countries outside the U.S., and, if so, how it should be measured to obtain cross-nationally comparable indicators. Both experimental and crossnational studies suggest that respondents should be given a clear opportunity to register a "non-identity" (Johnston, 1992; Blais et al., 2001; Sanders, Burton, and Kneeshaw, 2002). Such a question is available in the CSES data. Specifically, survey respondents were asked: "Do you usually think of yourself as close to any particular party?" Response categories were coded dichotomously, with 1 indicating a positive answer and 0 otherwise (no or don't know). ${ }^{12}$ This measure has been shown to be applicable not only in two-party systems, as in the U.S., but also in multi-party systems, and it has been 
shown to be valid across countries with variable partisan traditions and political institutions (Holmberg, 1994, 2003; Budge, Crewe, and Farlie, 1976).

\section{Parties}

\section{Goal Orientations}

Our measure of party goals is based on Laver and Hunt's (1992) expert surveys and indicates the extent to which parties prioritize office over policy. Specifically, experts were asked to evaluate each party on a twenty-point scale using the following question: "Forced to make a choice, would party leaders give up policy objectives in order to get into government, or would they sacrifice a place in the government in order to maintain policy objectives?" The response categories range from 1 to 20 , with higher values indicating a greater office-seeking party orientation. ${ }^{13}$ Using responses from multiple experts, Laver and Hunt calculated an average value for each party's relative priorities (for details, see Laver and Hunt (1992); and the appendix). ${ }^{14}$ Table 1 reports the average scores on the office orientation measure by party family; ${ }^{15}$ it reveals that conservative and agrarian parties are the most office oriented parties with the average scores above 13, while green and communist parties are least likely to trade their policy goals for office (with the average scores of 7.157 and 7.662 respectively).

(Table 1 about here)

\section{Party Position toward the Political System}

To measure party positions toward the political system, we relied on the Comparative Manifestos Project (CMP) data collected immediately prior to the CSES survey. Based 
on content analysis of party platforms issued before elections by human coders, the CMP is the only cross-national data collection project that includes indicators of party views towards the political system. Our reading of the original documents that the CMP data are based on revealed that statements coded under the rubric of "constitutionalism" provide the most appropriate indicator of a party's stance vis-à-vis the political system because they clearly reflect party positions about the fundamental rules of a political regime and maintaining its status quo. ${ }^{16}$

There are two categories of statements: first, "Constitutionalism: positive", which represents the extent to which a party supports specific aspects of the constitution, uses constitutionalism as an argument for policy, as well as generally approves of the constitutional way of doing things; and second, "Constitutionalism: negative", which reflects just the opposite. The statements in these categories commonly included proposals for institutional changes, such as creating a presidency with substantial powers (proposed by the Australian Labor Party in its 1996 manifesto), or resisting changes in the existing constitutional order on the basis that it is "the product of hundreds of years of knowledge, experience and history" (as the UK's Conservative Party proclaimed in its 1997 manifesto). ${ }^{17}$

In reading the manifestos, we found that parties often express support for some aspects of the constitutional order while criticizing others. Thus, to capture overall party positions toward the country's institutional structure, we created a combined constitutionalism index by subtracting the percentage of "Constitutionalism: negative" statements from the percentage of "Constitutionalism: positive" statements. ${ }^{18}$ The resulting variable ranges from -10.61 (Bloc Quebecois in Canada) to 6.69 (the Liberal 
Party in Canada) in our sample, with higher values indicating a more positive party position toward the political system. ${ }^{19}$ Looking at party scores on the constitutionalism index by party family (shown in Table 2) reveals that ethnic parties express the most negative positions about the desirability of existing political institutions and arrangements while liberal parties take the most positive positions (the average scores are -.511 and .581 respectively; the overall mean for 116 parties in our sample is .141).

(Table 2 about here)

Recent efforts to assess various approaches to measuring party policy positions have questioned the extent to which the CMP data reflect party policy positions as opposed to the relative salience of those policies (e.g., Benoit and Laver, 2007; Lowe et al., 2011). ${ }^{20}$ Conflating salience with positions poses a problem for studies of party competition that often seek to assess the extent of a genuine policy change in party positions over time using party locations on various policy dimensions - particularly the left-right continuum - derived from the CMP data. ${ }^{21}$

A closer look at the debate, however, reveals few grounds for concern for the purposes of our analysis. The CMP data is indeed grounded in the saliency theory (Robertson, 1976; Budge and Farlie, 1977; Budge et al., 2001). According to this theory, parties take up positions by emphasizing certain policy areas on which their positions are more credible while deemphasizing other policy areas. As a consequence, policy changes usually take place when parties de-emphasize previous priorities and take up new ones (Budge, 1994: 455). This perspective is designed to accommodate the fact that, while parties can take opposite positions on some issues, this is not possible with respect to 
valence issues (Stokes, 1963), such as environmental protection or corruption to which no direct counter-position is feasible (Volkens, Bara, and Budge, 2009).

The measures derived from the CMP data, however, have rarely been interpreted as indicators of policy saliency for political parties. Specifically, Lowe and his colleagues (2011) argue that, according to the saliency theory, parties should endorse only single sides of each issue, while the CMP's coding scheme makes numerous practical concessions to the fact that many issues are two-sided, such as positions on free trade, or on attitudes towards European integration. ${ }^{22}$ What is more, Benoit, Laver, and Mikhaylov (2009: 500) note that all CMP coding categories (except one, a seldom used category of economic goals) are explicitly positional in their definitions, as they refer to "favorable mentions of ... “, "need for...', etc., and have been treated as indicators of policy positions rather than saliency by most researchers. In light of this discussion and the fact that our measures - "constitutionalism: positive" and "constitutionalism: negative" - are also based on the bi-polar coding scheme of the CMP data, we believe it is safe to interpret them as indicators of party positions towards the political system rather than saliency.

\section{Analysis}

Do office-seeking parties express more positive opinions about the political system than policy-seeking parties? And do partisans of parties that communicate positive views about the constitutional status quo express more support for the political system in their country than citizens who identify with parties with negative views? Figures 1 and 2 offer some preliminary evidence at the aggregate level of the connections 
between party goals, party positions about the political system, and citizens' legitimacy beliefs.

To examine whether parties' goal orientations are related to their positions on the desirability of the political system, we calculated the average score on the constitutionalism index for parties with different goal orientations (Figure 1). ${ }^{23}$ Our calculations show that, on average, political parties with a preference of office over policy take more positive positions regarding the constitutional status quo than other parties. In contrast, policy-seeking parties on average are more likely to take a negative position, with parties that balance between policy and office expressing a mild endorsement of the existing political order. The scores on the constitutionalism index for office- and policy-seeking parties are +.414 and -.606 respectively, while parties that balance between policy and office take a more neutral position on the political system $(+.146)$.

To examine whether party statements about the political system are linked to citizens' legitimacy beliefs, we compared democracy satisfaction and external efficacy between nonpartisans and partisans of parties with high, low, and medium levels of support for the constitutional status quo (Figure 2). ${ }^{24}$ The data reveal patterns strongly consistent with our theoretical priors. Citizens' attitudes toward the functioning of the political system vary according to party views about the existing political order. Figure 2 shows that about 88 percent of respondents who feel close to parties with high scores on the constitutionalism index are fairly or very satisfied with the democratic process in their country, while only 58 percent of partisans of parties with low scores and 75 percent of identifiers with parties with medium scores express such views. In comparison, 72 
percent of non-partisans report being satisfied with democracy, which places them above partisans of parties with low support for the constitutional status quo, but below partisans of parties with medium and high support for the political system.

A similar pattern emerges when we look at external efficacy, with partisans of parties with high constitutionalism scores expressing the most positive attitudes about the responsiveness of the political system: 71 percent of these partisans scored high on the external efficacy scale, while the numbers for partisans with medium and low constitutionalism values were 63 and 55 percent, respectively. In comparison, nonpartisans report the lowest levels of external efficacy with 53 percent agreeing that the political system is responsive. Taken together, citizens who identify with parties that adopt positive views about the constitutional status quo express significantly more optimistic attitudes about the functioning of the political system than partisans of other parties and non-partisans. And while a lack of partisanship clearly undermines external efficacy beliefs, the pattern is less clear cut with respect to satisfaction with democracy, where partisans of parties with negative positions express even more negative views than non-partisans.

(Figures 1 and 2 about here)

To establish how sizable and robust these relationships are once other factors are controlled for, we sought to estimate multivariate models of support for the political system. As discussed above, existing research provides strong reasons to expect the causal arrow to run from parties' messages to partisans' views, rather than reverse. However, in devising a proper estimation strategy, we sought to account for possible endogeneity by employing a two-stage instrumental variable (IV) approach (Baum, 2006; 
for application in political science, see Gabel and Scheve, 2007). Instrumental variable estimation purges the potentially endogenous regressor - in our case party positions towards the constitutional status quo - of variation that is not a function of exogenous variables. ${ }^{25}$ IV estimation is not a costless solution, however: IV estimates are less efficient compared to OLS and can be biased if the assumptions of the model are violated. We therefore needed to identify instruments that are valid, that is, have a significant partial correlation with party positions towards the constitutional status quo, controlling for all other exogenous determinants of citizens' support for the political system, while being uncorrelated with the error term in the model of citizens' support for the political system.

We posit that party goal orientation and party seat-vote disproportionality can be used as such instruments. As we argued above, office-seeking parties adopt more positive positions towards the existing political system than policy-seeking parties. Office-seeking parties are less encumbered by party activists' policy preferences, are freer to maximize (re-)election (Strøm, 1990), and therefore are more likely to be electorally competitive, get elected to office, and implement their preferred policies. Moreover, because officeseeking parties are more likely to become parties in parliament and government, they are also more likely to write the rules of the game and be in charge of enforcing them than parties outside of government or parliament. As a consequence, they are also more likely to benefit from the status quo of a political system, and hence express more positive views about it than policy-seeking parties.

Parties with a larger share of legislative seats than their share of votes can be similarly expected to express stronger support for the political system than parties that 
received a smaller percentage of seats in comparison to their votes in national elections. Translation of votes into seats has been shown to play an important role in shaping party strategies and behavior, including party efforts to push for constitutional changes, especially in electoral systems (Colomer, 2005; Benoit, 2004, 2007). And while institutional changes and vote-seat dis-proportionality have traditionally been studied at the level of countries rather than parties, the underlying assumption of agent-based models of institutional change is that parties adopt different positions towards the status quo of the political system, in large part driven by party perceptions of how much they are advantaged or disadvantaged by existing political institutions.

While office orientation and party seat-vote dis-proportionality matters for how parties evaluate the political system, we know of no studies arguing that these factors directly influence citizens' legitimacy beliefs. Thus, we have theoretical and empirical reasons to justify the selection of our instruments; however, we still need to demonstrate that our instruments meet the assumptions for the IV approach to provide consistent estimates. The assumption that the instruments are statistically independent from the disturbance process cannot be verified in the data directly (Baum, 2006: 191). However, since our model is over-identified we can provide evidence that instruments are adequate by reporting test statistics below. ${ }^{26}$

We report the results of two-stage IV estimations in Table 3 and Table 4. The first stage is designed to predict party positions towards the constitutional status quo using our instruments - party office orientation and party vote-seat disproportionality (measured by subtracting the percentage of party votes from the percentage of party seats in previous national election) - while controlling for all variables specified in the model of citizen 
support for the political system and country fixed effects, and estimating our models using robust standard errors (see Arceneaux and Nickerson 2009). ${ }^{27}$ The second stage employs instrumented party position towards the constitutional status quo as an independent variable in the model of citizen support for the political system, controlling for other determinants of people's attitudes towards their political system, including country fixed effects and using robust standard errors (see the appendix for detailed information on variable coding).

The first stage of the IV estimations, reported in Table 3, indicates that both instruments have the anticipated signs and are significantly correlated with party support for the constitutional status quo. We find that, controlling for all predictors of citizen support for the political system as well as country dummy variables, political parties with office orientation report more support for the political system in their manifestos than policy-seeking parties. Similarly, parties that enjoy higher share of legislative seats than the proportion of votes they received in previous national election express more positive views about the constitutional status quo than parties who received fewer seats than they deserve given their vote share.

To systematically asses the validity of our instruments, we rely on several test statistics. First, the F-statistic for test of excluded instruments is equal to 384 and the Fstatistic is significant at less than .001 , indicating that our instruments are jointly significant. Furthermore, the Hansen J-test statistic in all models reported in Table 4 is statistically insignificant, indicating that the instruments are appropriately uncorrelated with the error term in the second-stage estimations. Taken together, the results show that 
the selected instruments are relevant and statistically independent from the disturbance process, satisfying the key requirements of valid instruments of the IV approach.

(Table 3 and 4 about here)

Table 4 presents the results of the second stage estimations that employ the exogenously derived measure of party position toward the political system to explain citizens' views about the political system. We provide two sets of results: first, we report the findings for all respondents. We do so to test two mechanisms by which partisanship can be expected to influence citizens' attitudes towards the political system: 1) the traditional view, according to which partisanship should increase people's support for the political system regardless of the opinions parties express about the constitutional status quo, ${ }^{28}$ and 2) party persuasion view, according to which party positions should influence their partisans' legitimacy beliefs. To put the latter expectation to a more rigorous test, we then estimate our model using the sample of partisans only.

In the second-stage estimations, we control for whether respondent's preferred party is in government because winners have been shown to be more satisfied with democracy in their country than other voters (Anderson et al., 2005; Anderson and Guillory, 1997; Ginsberg and Weissberg, 1978; Nadeau and Blais, 1993; Norris, 1999). We also include respondent's left-right self-placement because right-wing ideology is usually associated with conservatism and stronger support for the existing status quo, while left-wing orientations - with openness to change and more critical attitudes towards the political system (Anderson and Singer, 2008). Furthermore, since radical views usually lead to more dissatisfaction with a political system and a willingness to mobilize for change (Riker, 1982; Anderson et al., 2005, ch.5), we include a measure capturing 
individual's distance from the country's median on the left-right continuum. In addition, we sought to identify citizens with a greater stake in the maintenance of the societal status quo using variables such as income, education, and unemployment, as well as gender and race, which reflect citizens' socioeconomic status or political resources (Almond and Verba, 1963; Anderson et al., 2005: 20) At the party level, we additionally control for party distance from the country's median on the left right-continuum and party share of legislative seats, and include country fixed effects to capture cross-country heterogeneity in public support for the political system (see appendix for survey question wording and variable coding for all measures).

The results of the second stage estimations are in line with our expectations. ${ }^{29} \mathrm{We}$ find that partisans' beliefs about the performance of the political system are consistent with their parties' support for the constitutional status quo. That is, partisans whose parties take more positive positions toward the political system express higher levels of satisfaction with the way democracy works and report higher levels of confidence that the political system is responsive to them. These findings hold when we estimate our model using all respondents (partisans and non-partisans), as well as when we run our analyses on a reduced sample of partisans only. Hence, we find that parties play an important role in shaping their partisan views about the political system. At the same time, the results for all respondents show that partisanship exerts a direct positive effect on citizens' external efficacy, regardless of party outlook toward the political regime. Thus, individuals who are attached to parties are more likely to believe that the system is responsive to their preferences and demands than non-partisans. ${ }^{30}$ 
The other control variables produce results consistent with prior research. We find that supporting the government and having positive evaluations of economic performance increase citizen satisfaction with democracy and their sense of external efficacy. What is more, the results show that higher income and education contribute positively to public support for the political system, as does being young and male. Moreover, right-wing ideological self-placement is linked to stronger legitimacy beliefs. However, ideological extremity has divergent effects on our two dependent variables: while it tends to reduce citizen satisfaction with democracy, it enhances people's sense of external efficacy.

How much does party support for political system matter in shaping their partisan legitimacy beliefs? To assess our results in greater detail, we calculated the marginal effects of party position toward the constitutional status quo on partisans' legitimacy beliefs using the results for partisans reported in Table $4 .{ }^{31}$ Figure 3a plots the magnitude of this effect for the satisfaction with democracy variable, and Figure $3 b$ - for external efficacy. The dark-grey bars indicate the levels of system support among partisans whose parties express positive views about the system ( 1 standard deviation above the average constitutionalism score in our sample of parties), while white bars report the levels of system support among identifiers of parties with negative views (1 standard deviation below the average constitutionalism value); the vertical bars show the $95 \%$ confidence intervals.

Calculations of the substantive effects reveal that party positions toward the political system have a sizable impact on their partisans' legitimacy beliefs. Specifically, satisfaction with democracy among partisans of parties that express positive views is .43 units higher than levels of satisfaction among those who identify with parties that take 
negative positions (2.432 vs. 2.003$)$. Similarly, the predicted level of external efficacy among supporters of parties positively oriented toward the system is 5.196 compared to 4.438 for partisans of parties with negative views (a difference of .758). In short, what parties say about the political system in their country has a powerful impact on their partisans' legitimacy beliefs, and this effect is consistent and statistical significant across different measures of legitimacy beliefs. ${ }^{32}$

(Figures $3 \mathrm{a}$ and $3 \mathrm{~b}$ about here)

\section{Discussion}

Modern democracies are party democracies. Yet, political parties have yet to take center stage when it comes to how citizens evaluate the political system. This study was designed to show that political parties play an important role in shaping citizens' views about the system. As organizations, political parties pursue a variety of goals; while some put greater emphasis on winning office, others are willing to forego office in the pursuit of policy objectives. And these organizational goals, we argue, affect what supporters think about the political system because office-oriented parties have an incentive to take more positive positions about the political regime, while policy-seeking parties take a more critical stance.

Partisanship provides the critical link between party elites and party supporters in communicating views about the political system. By communicating their positions, office- and policy-seeking parties engender different levels of enthusiasm for the status quo among their supporters. As a result, political parties actively shape the beliefs citizens adopt about the functioning of democratic governance in their country. Using survey data collected in 15 countries and data on parties' goals and positions for 116 
parties, we find that party positions do influence public support for the political regime and that this effect is not an artifact produced by strategic position taking by parties.

We find that supporters of political parties with more positive views about the political system tend to be more satisfied with democracy and report higher levels of external efficacy than partisans of parties with pessimistic opinions. Moreover, we find that non-partisans are more satisfied with democracy than citizens who identify with parties with a negative outlook towards the political system but less satisfied than partisans of parties with positive positions. However, a lack of partisanship has an overwhelming negative effect on citizens' external efficacy beliefs, as non-partisans are considerably more pessimistic about the responsiveness of the political system than partisans of any party. Finally, we find that party positions toward the system are driven by the goals they pursue when faced with a trade-off between office and policy. Officeseeking parties express more support for the status quo of the existing regime and thus lead to more satisfaction with the system among their supporters compared to policyoriented parties.

By integrating research on party goals, party programs, partisanship, and democratic legitimacy, we sought to make a contribution to each of these literatures. Regarding the literature on democratic legitimacy, our findings suggest that parties clearly have the capacity to mobilize consent or dissent from above. Thus, legitimacy is as much a process of bottom-up politics where citizens hold the political system accountable for its performance, as it is a process of top-down politics where strategic elites seek to further their own goals, sometimes at the expense of the broader body politic. We need not resort to extreme examples like the failure of the Weimar Republic 
to appreciate this point - examples of party elites shaping the views of their supporters abound in a variety of policy areas (e.g., Sniderman and Hagendoorn, 2007; Gabel and Scheve, 2007). Whether this mobilization of consent, born of the parties' self-interested strategic calculations as office seekers and status quo defenders, is desirable is a normative question that hitherto has not been asked. We suggest that, at a minimum, it is worth thinking about.

Our study also contributes to the literature that seeks to explain the causes and consequences of parties' policy positions. While these have mostly been studied from a cross-national perspective with an eye toward the quality of democratic representation (Kim, Powell, and Fording, 2010; McDonald and Budge, 2005), or how the translation of voters' preferences into government policy shapes citizen support for the political system (Paskeviciute, 2006), our study suggests that parties' positions on the functioning of the political system can also be fruitfully understood to shape the foundations of citizens' legitimacy beliefs.

In a curious way, then, our findings reinforce Dalton's concerns that a loosening of the connection between political parties and citizens observed in established democracies may indeed undermine mass support for the democratic governance. And this is likely to happen not only because the lack of partisanship will weaken citizen attachment to a political system generally. Given that political elites are usually more supportive of democratic principles than are ordinary citizens (Sullivan et al., 1993; Converse and Pierce, 1986), support for the political system may be eroding because citizens are less likely to be affected by the positive messages office-seeking parties 
articulate about the system. Thus, in times of de-aligned citizens, legitimacy from above is harder to come by. Whether this is such a terrible state of affairs remains to be seen. 


\section{Notes}

${ }^{1}$ See also Norris (1999), Pharr and Putnam (2000), and Dalton (2004).

${ }^{2}$ In the rational choice perspective, such an attachment is more of a cognitive short cut representing a running tally of retrospective assessments of party performance (Fiorina, 1981).

${ }^{3}$ To say that politicians act as entrepreneurs and are motivated by the desire to get into office and convert office-benefits into private goods (Downs, 1957; Enelow and Hinich, 1984; Strøm, 1990; Müller and Strøm 1999) is not to say that policy is unimportant to them (Hunt and Laver, 1992). After all, only policy-oriented individuals are likely to become party leaders in the first place (Laver, 1997: 84-85). However, the extent to which party leaders are capable of pursuing office when faced with a trade-off between policy and office is determined by a number of factors, including a party's organizational structure as well as electoral, legislative, and governmental institutions (Strøm, 1990; Müller and Strøm, 1999).

${ }^{4}$ This argument about the positive positions about the state and its structure that office-seeking parties are likely to take is also consistent with scholarship on the changing character of party organization. In particular, it dovetails with the conceptual development and identification of socalled "cartel parties" (Katz and Mair, 1995). In contrast to traditional "catch all" parties that emerged in the 1950s and 1960s and that were based primarily on mass membership, or cadre parties that relied on a small band of committed party members (Kirchheimer, 1966), the primary characteristic of the modern cartel party is its intimate relationship with the state. In Katz and Mair's classification scheme, cartel parties have in fact become "agents of the state" (Wolinetz, 2002: 148). While the idea of cartel parties is not uncontested (see, e.g., Koole, 1996), scholars have come to see the concept of cartel parties and the classification of parties according to their goal orientations as theoretically compatible and complementary. In particular, because the success and survival of cartel parties require access to predictable sources of revenue from the state and privileged access to (often publicly owned or financed) mass media (including 
television), office-seeking parties collude in sharing the resources for their collective survival, which at the same time in a cartel-like manner bars newcomers from entering the system. Thus, Wolinetz (2002) recently proposed a simple way to integrate parties' goal orientations and theories of party organizational change by arguing that office-seeking parties also are typically cartel parties.

${ }^{5}$ The Vlaams Blok was dissolved after a Belgian court convicted it of repeated incitement to discrimination in 2004. It reconstituted itself as Vlaams Belang shortly thereafter.

${ }^{6}$ Please note that we hypothesize party persuasion effects only among partisans, not all voters. This is because our study is designed to test the consequences of partisanship for people's attitudes towards the political system, and, as we argue above, one of the mechanisms by which partisanship does so is by enabling party persuasion of their partisans.

${ }^{7}$ For useful literature overviews, see Johnston (2006) and Holmberg (2007).

${ }^{8}$ Studies of public opinion based on panel data show that partisanship causally precedes people's attitudes and values. For example, analyses of the interdependence of respondents' issue positions (on social welfare, race, and culture) and partisanship show that party attachment influences people's issue positions much more strongly than issue positions influence partisanship (Layman and Carsey, 2002; Carsey and Layman, 2006). As well, consistent with the limited evidence that exists about the link between legitimacy beliefs and partisanship (Koch, 2003), Goren's (2005) structural equation model of three-wave panel data reveal that partisanship affects people's political values more strongly than the reverse. Similarly, recent reevaluation of the priming effects (Lenz 2009) showed that electoral campaign and media attention often leads individuals to learn party issue positions and then to adopt the position of their preferred party as their own (but see Adams, Ezrow, and Somer-Topcu 2011).

${ }^{9}$ Our party and survey data are drawn from different time periods, and their causal ordering is as our theory implies. Specifically, the Comparative Manifestos Project data are very close, yet 
always temporally prior to, the CSES data. This is because all manifestos are pre-election documents and CSES surveys in our data are post-election surveys, and the interviews were usually carried out shortly after the elections. Our measures of party goals from the Laver and Hunt (1992) expert surveys were collected between 1989 and 1992. Although this is at least four years earlier than the CSES data, the temporal distance should not be a problem given that expert surveys such as the Laver and Hunt survey are excellent measures of long-term general tendencies in party goals that reflect longstanding organizational strategies and constraints rather than tactical behavior at any point in time.

${ }^{10}$ The Cronbach's alpha for these two items is .62, indicating that they could be combined into a single index.

${ }^{11}$ The CSES data include two additional items that could be considered as indicators of external efficacy: 1) who people vote for makes a difference, and 2) who is in power can make a difference. Unfortunately, the Cronbach's alpha of adding one or both of these items to the indicators we already use for our external efficacy measure (or combining these two items together into a separate index) fails to achieve the necessary level of .6, suggesting that we should not add these items into a single index. However, estimating our models for each external efficacy item separately produces consistent and statistically significant results that in line with our expectations in three out of four cases (the positive coefficient fails to achieve the conventional levels of statistical significance only for "who is in power can make a difference" (the results are available from authors upon request).

${ }^{12}$ An alternative would be constructing a four-category measure of party identification suggested by Holmberg (2003) that not only accounts for the presence or absence of partisanship but also for its intensity. However, survey items necessary for creating such more finely-grained measure were not available for Australia, Belgium, Canada, and New Zealand. We therefore opted to rely on a dichotomous indicator of party identification in the models reported below. To test the 
robustness of our results, we also estimated our models using full partisanship scale for the countries where such measure is available (the results available from the authors upon request). The results were in line with our expectations. Moreover, they revealed that the impact of party messages about the desirability of the political regime was particularly powerful among strong party identifiers in shaping their legitimacy beliefs, suggesting that party persuasion increases with partisanship intensity.

${ }^{13}$ Thus, it does not assume that policy-seeking parties do not care about office; only that, when faced with a trade-off, they are more likely to give a preference to policy rather than office.

${ }^{14}$ Very small parties not listed in the CMP data were not included in the analysis (for more information, see our description of the CMP data and measures below). We therefore also examined the robustness of our results to the inclusion of these parties by coding them as neutral (10) - that is, they were assumed to be balancing between office and policy motivations. When we do so, our results do not change appreciably, and our inferences remain the same.

${ }^{15}$ We relied on the CMP codes to classify parties into different party families with one additional modification. Since the CMP data does not have a separate category for extreme right parties, we identified these parties following Golder (2003) and Norris (2005), and recoded party family measures so that they can accommodate this additional category.

16 The CMP data are particularly useful to test our conjecture because they are manifestoes designed to win voter support. As such, they are clearly aimed at voters, but may also reflect the different campaign strategies of office-seeking and policy-seeking parties. While we cannot test this possibility here, it is plausible that parties with different goal orientations may seek to change the nature of the debate in elections, with office-seeking parties seeking to frame the election as a debate over issues and candidates and policy-seeking parties interested in making it a debate over the political system and how well it works to represent voters. 
${ }^{17}$ We are grateful to Andrea Volkens and Paul Pennings for making the original coded party manifestos available to us.

${ }^{18}$ The CMP indicators represent percentages of party statements within party platforms designed to address each of the 56 issues within the CMP classification scheme. This means that the possible range on each measure is from $0 \%$ (when a party does not mention the issue at all) to a maximum theoretical value of $100 \%$ (when all statements within a manifesto focus on the issue) ${ }^{19}$ One shortcoming of the CMP data is that they provide measures only for parties that won two or more seats in parliament, ignoring smaller parties. To keep at least some smaller parties in our analyses, we made the following decisions: we excluded small parties that never appeared in the CMP data from beginning of its coverage in 1950 until the CSES survey. However, we kept parties that failed to appear in the CMP data in the election just before the CSES survey but were included in the CMP data in previous elections. There were 10 such parties, increasing our sample of parties from 106 to 116 . We assigned these small parties a value of 0 on the constitutionalism index, which assumes that they take a neutral position towards the political system. Since parties without legislative representation are more likely to be dissatisfied with the political system and its institutions than parties in parliament (please note that our analyses control for party legislative size), coding them this way offers a conservative test of our hypotheses - that is, it makes it harder to uncover the expected effects on partisan attitudes toward the political system. Excluding all small parties from the analyses, however, does not change our results appreciably, and our inferences remain the same (the results are available from the authors upon request).

${ }^{20}$ See also the special issue in Electoral Studies (2007), vol. 6, issue 1.

${ }^{21}$ This problem is further magnified by the absence of measurement error of the CMP indicators - a consequence of each party manifesto being coded by one expert coder (Benoit, Laver, and 
Mikhaylov, 2009; Benoit and Laver, 2007; but see Volkens, 2007; Volkens, Bara, and Budge, 2009).

${ }^{22}$ Lowe et al. (2011) point out that even environmental protection (considered as one-sided issue in the CMP data) could be easily paired with pro-growth positions, and this is in fact how other approaches to measuring party policy positions have expressed the environmental policy dimension (Benoit and Laver, 2006; Laver and Hunt, 1992).

${ }^{23}$ For the purpose of this figure, we defined policy-seeking parties as parties that scored equal to or below 7 on the 1-20 office-seeking scale and office-seeking parties as those with a score above 13 on the scale; balancing parties score between 7 and 12 on the scale.

${ }^{24}$ High support for the constitutionalism status quo is defined as party positions with values 1 standard deviation or more above the mean of the constitutionalism index, low support -1 standard deviation or more below the mean, and medium - values than fall between $+/-1$ standard deviation from the mean.

${ }^{25}$ IV estimates also eliminate bias due to omitted variables and measurement error (Baum 2006; Gabel and Scheve, 2007).

${ }^{26}$ For a similar approach, see Gabel and Scheve (2007).

${ }^{27}$ Note that due to the inclusion of country fixed effects, identification in this model comes from within country variation in party characteristics.

${ }^{28}$ According to our model, non-partisans do not have a 'party position', but we assigned them a value of zero on the constitutionalism index so that we could keep them in the analyses because testing the traditional perspective requires that we include both partisans and non-partisans.

${ }^{29}$ Recall that the measure of party position towards the constitutional status quo was incorporated in the individual level data by assigning partisan respondents the value of their party positions. Technically, this means that this variable is an interaction term of partisanship and (instrumented) party position. 
${ }^{30}$ To test the robustness of our results, we conducted several additional analyses: we re-estimated our models 1) without extreme right and communist parties; 2) without small parties (see endnote 19 above); 3) using a disaggregated external efficacy index - that is, estimating our models for each external efficacy item in the CSES data (see endnote 11); 4) using the full party identification measure for a reduced number of countries where this measure is available to see whether party persuasion effects strengthen with partisanship intensity (see endnote 12); 5) using multi-level statistical techniques in the second stage of our analyses instead of the IV estimations; 6) using exactly identified equation with party office orientation as a single instrument; 7) to test that party positions about the political system influence citizens' satisfaction with democracy and external efficacy but not internal efficacy, such as citizens' beliefs about whether people in their country express or hide what they think about politics; 8) using an interaction term between party positions and the number of days since election to test whether the impact of party positions is weakened by temporal distance of the CSES survey date from election. In all cases, our findings were in line with our expectations and our inferences remained the same (the results are available from the authors upon request).

31 We hold other variables at their means and dichotomous variables at their medians; all country dummies, except Denmark, are set to zero.

32 To test the robustness of our results, we disaggregated our external efficacy index and estimated our models for each external efficacy item. The results (available from the authors upon request) do not change and our inferences remain the same. 


\section{References}

Adams, J. (2001), Party Competition and Responsible Party Government, Ann Arbor, MI: University of Michigan Press.

Adams, J., L. Ezrow and Z. Somer-Topcu (2011), 'Is Anybody Listening? Evidence that Voters Do Not Respond to European Parties' Policy Statements During Elections', American Journal of Political Science 55(2): 370-382.

Aldrich, J. H. (1995), Why Parties? The Origin and Transformation of Political Parties in America, Chicago, IL: The University of Chicago Press.

Almond, G.A. and S. Verba (1963), The Civic Culture, Boston: Little, Brown.

Anderson, C.J. and C.A. Guillory (1997), 'Political Institutions and Satisfaction with Democracy: A Cross-National Analysis of Consensus and Majoritarian Systems', American Political Science Review 91(1): 66-82.

Anderson, C.J. and Y.V. Tverdova (2003), 'Corruption, Political Allegiances, and Attitudes toward Government in Contemporary Democracies', American Journal of Political Science 47(1): 91-109.

Anderson, C.J., A. Blais, S. Bowler, T. Donovan and O. Listhaug (2005), Losers' Consent: Elections and Democratic Legitimacy, New York: Oxford University Press.

Arceneaux, K., and D.W. Nickerson. (2009), "Modeling Certainty with Clustered Data: A Comparison of Methods", Political Analysis 7 (2): 177-90.

Balch, G.I. (1974), 'Multiple Indicators in Survey Research: The Concept Sense of Political Efficacy', Political Methodology 1(1): 1-43.

Baum, C.F. (2006). An Introduction to Modern Econometrics Using Stata. College Station, TX: Stata Press.

Benoit, K. (2004), 'Models of Electoral System Change', Electoral Studies 23(3): 363-389.

Benoit, K. (2007), 'The Electoral Laws as Political Consequences: Explaining the Origins and Change of Electoral Institutions', Annual Review of Political Science 10: 363-390.

Benoit, K. and M. Laver (2006), Party Policy in Modern Democracies, London: Routledge.

Benoit, K. and M. Laver (2007), 'Estimating Party Policy Positions: Comparing Expert Surveys and Hand-coded Content Analysis', Electoral Studies 26(1): 90-107.

Benoit, K., M. Laver and S. Mikhaylov (2009), 'Treating Words as Data with Error: Uncertainty in Text Statements of Policy Positions', American Journal of Political Science 53(2): 495-513.

Blais, A., E. Gidengil, R. Nadeau and N. Nevitte (2001), 'Measuring Party Identification: Britain, Canada, and the United States', Political Behavior 23(1): 5-22.

Budge, I. (1994), 'A New Spatial Theory of Party Competition: Uncertainty, Ideology and Policy Equilibria Viewed Comparatively and Temporally', British Journal of Political Science 24(4): 443-467.

Budge, I., I. Crewe and D. J. Farlie (eds.) (1976), Party Identification and Beyond, New York: John Wiley.

Budge, I. and D. J. Farlie (1977), Voting and Party Competition, London and New York: Wiley.

Budge, I., H-D. Klingemann, A.Volkens, J. Bara and E.Tanenbaum (2001), Mapping Policy Preferences: Estimates for Parties, Electors, and Governments 1945-1998, Oxford: Oxford University Press.

Bunce, V. (2003), 'Rethinking Recent Democratization: Lessons from the Postcommunist Experience', World Politics 55(2): 167-192.

Campbell, A., G. Gurin and W.E. Miller (1954), The Voter Decides, Evanston, IL: Row, Peterson.

Campbell, A., P.E. Converse, W.E. Miller and D. E. Stokes (1960), The American Voter, New York: Willey. 
Campbell, A., P.E. Converse, W.E. Miller and D.E. Stokes (1966), Elections and the Political Order, New York: Wiley.

Carsey, T.M. and G.C. Layman (2006), 'Changing Sides or Changing Minds? Party Identification and Policy Preferences in the American Electorate', American Journal of Political Science 50(2): 464-477.

Clarke, H.D., N. Dutt and A. Kornberg (1993), 'The Political Economy of Attitudes toward Policy and Society in Western European Democracies', Journal of Politics 55(4): 9981021.

Colomer, J.M. (2005), 'It's Parties that Choose Electoral Systems (or, Duverger's Laws Upside Down', Political Studies 53(1): 1-21.

Converse, P.E. and R. Pierce (1986), Political Representation in France, Cambridge, MA: Harvard University Press.

Dalton, R.J. (1996), Citizen Politics: Public Opinion and Political Parties in Advanced Western Democracies, $2^{\text {nd }}$ ed. Chatham, NJ: Chatham House.

Dalton, R.J. (1999), 'Political Support in Advanced Industrial Democracies', in P. Norris (ed), Critical Citizens: Global Support for Democratic Government, Oxford: Oxford University Press, pp. 57-77.

Dalton, R.J. (2004), Democratic Challenges, Democratic Choices: The Erosion of Political Support in Advanced Industrial Democracies, New York: Oxford University Press.

Dalton, R.J. and S. Weldon (2007), 'Partisanship and Party System Institutionalization', Party Politics 13(2): 179-96.

Downs, A. (1957), An Economic Theory of Democracy, New York: Harper and Row.

Enelow, J.M. and M. J. Hinich (eds) (1984), The Spatial Theory of Voting, New York: Cambridge University Press.

Erikson, R.S. and D.W. Romero (1990), 'Candidate Equilibrium and the Behavioral Model of the Vote', American Political Science Review 84(4): 1103-1126.

Fiorina, M.P.(1981), Retrospective Voting in American National Elections, New Haven: Yale University Press.

Franklin, C.H. (1984), 'Issue Preferences, Socialization, and the Evolution of Party Identification', American Journal of Political Science 28(3): 459-478.

Franklin, C.H. and J.E. Jackson (1983), 'The Dynamics of Party Identification', American Political Science Review 77(4): 957-973.

Fuchs, D., G. Guidorossi and P. Svenson (1995), 'Support for the Democratic System', in H-D. Klingemann and D. Fuchs (eds), Citizens and the State, New York: Oxford University Press, pp: 323-353.

Fuchs, D. and H-D. Klingemann (1995), 'Citizens and the State: A Changing Relationship?', in H-D. Klingemann and D. Fuchs (eds), Citizens and the State, New York: Oxford University Press, pp. 1-23.

Gabel, M. and K. Scheve (2007), 'Estimating the Effect of Elite Communications on Public Opinion Using Instrumental Variables', American Journal of Political Science 51(4): 1013-1028.

Geddes, B. (1999), 'What Do We Know About Democratization After Twenty Years?', Annual Review of Political Science 2: 115-44.

Ginsberg, B. and R. Weissberg (1978), 'Elections and the Mobilization of Popular Support', American Journal of Political Science 22(1): 31-55.

Golder, M. (2003), "Explaining Variation in the Success of Extreme Right Parties in Western Europe", Comparative Political Studies 36(4): 432-466.

Goren, P. (2005), 'Party Identification and Core Political Values', American Journal of Political Science 49(4): 881-96.

Green, D.P., B. Palmquist and E. Schickler (2002), Partisan Hearts and Minds: Political Parties and the Social Identity of Voters, New Haven: Yale University Press. 
Harmel, R. and J.D. Robertson (1986), 'Government Stability and Regime Support: A CrossNational Analysis', Journal of Politics 48(4): 1029-1040.

Hess, R. and J. Torney (1967), The Development of Political Attitudes in Children, Chicago: Aldine.

Hibbing, J.R. and E. Theiss-Morse (1995), Congress as Public Enemy, New York: Cambridge University Press.

Holmberg, S. (1994). 'Party Identification Compared across the Atlantic', in W.E. Miller, M. K. Jennings and T. E. Mann (eds), Elections at Home and Abroad. Essays in Honor of Warren E. Miller, University of Michigan Press, Ann Arbor, pp.93-121.

Holmberg, S. (2003), 'Are Political Parties Necessary?', Electoral Studies 22(2): 287-299.

Johnston, R. (1992), 'Party Identification Measures in the Anglo-American Context: A National Survey Experiment', American Journal of Political Science 36(2): 542-559.

Johnston, R. (2006), 'Party Identification: Unmoved Mover or Sum of Preferences?', Annual Review of Political Science 9: 329-351.

Jacoby, W.G. (1988), 'The Impact of Party Identification on Issue Attitudes', American Journal of Political Science 32(3): 643-661.

Katz, R. and P. Mair (1995), 'Changing Models of Party Organization and Party Democracy: The Emergence of the Cartel Party', Party Politics 1(1): 5-27.

Kim, H.M., G.B. Powell and R.C. Fording (2010), 'Electoral Systems, Party Systems, and Ideological Representation: An Analysis of Distortion in Western Democracies', Comparative Politics 42(2): 167-185.

Kirchheimer, O. (1966), 'The Transformation of the Western European Party Systems', in J. LaPalombara and M. Weiner (eds), Political Parties and Political Development, Princeton, NJ: Princeton University Press, pp. 177-200.

Klingemann, H-D. (1999), 'Mapping Political Support in the 1990s: A Global Analysis', in P. Norris (ed), Critical Citizens: Global Support for Democratic Governance, Oxford: Oxford University Press, pp. 31-57.

Klingemann, H-D., A. Volkens, I. Budge, J. Bara and M.D. McDonald (2006), Mapping Policy Preferences II: Estimates for Parties, Electors, and Governments in Eastern Europe, European Union, and OECD 1990-2003, New York: Oxford University Press.

Koch, J.W. (2003), 'Political Cynicism and Third Party Support in American Presidential Elections', American Politics Research 31(1): 48-65.

Koole, R. (1996), 'Cadre, Catch-all or Cartel? A Comment on the Notion of the Cartel Party', Party Politics 2(4): 507-527.

Lane, R.E. (1959), Political Life. Why People Get Involved in Politics, New York: The Free Press.

Laver, M. (1997), Private Desires, Political Action, London: Sage Publications.

Laver, M. and W. B. Hunt (1992), Policy and Party Competition, New York: Routledge.

Layman, G.C. and T.M. Carsey (2002), 'Party Polarization and "Conflict Extension" in the American Electorate', American Journal of Political Science 46(4): 786-802.

Lenz, G.S. (2009), 'Learning and Opinion Change, Not Priming: Reconsidering the Priming Hypothesis', American Journal of Political Science 53(4): 821-837.

Levi, M. (1997), Consent, Dissent and Patriotism, New York: Cambridge University Press.

Levi, M. and L. Stokes (2000), 'Political Trust and Trustworthiness', Annual Review of Political Science 3: 475-507.

Linde, J. and J. Ekman (2003), 'Satisfaction with Democracy: A Note on Frequently Used Indicator in Comparative Politics', European Journal of Political Research 42(3): 391408.

Lipset, S.M. (1959), Political Man: The Social Bases of Politics, Garden City, NY: Doubleday.

Lowe, W., K. Benoit, S. Mikhaylov and M. Laver (2011), 'Scaling Policy Preferences from Coded Political Texts', Legislative Studies Quarterly 26(1): 123-155. 
McDonald, M.D. and I. Budge (2005), Elections, Parties, Democracy: Conferring the Median Mandate, New York: Oxford University Press.

Miller, A.H. and O. Listhaug (1990), 'Political Parties and Confidence in Government: A Comparison of Norway, Sweden, and the United States', British Journal of Political Science 20(3): 357-86.

Miller, A.H. and O. Listhaug (1999), 'Political Performance and Institutional Trust', in P. Norris (ed), Critical Citizens: Global Support to Democratic Governance, Oxford: Oxford University Press, pp. 204-217.

Miller, E. W. and J.M. Shanks (1996), The New American Voter, Cambridge, MA: Harvard University Press.

Mishler, W. and R. Rose (1997), 'Trust, Distrust, and Skepticism: Popular Evaluations of Civil and Political Institutions in Post-Communist Societies', Journal of Politics 59(2): 419451.

Mishler, W. and R. Rose (2001), 'What are the Origins of Political Trust? Testing Institutional and Cultural Theories in Post-Communist Societies', Comparative Political Studies 34(1): 30-62.

Müller, W.C. and K. Strøm (1999), Policy, Office, or Votes? How Political Parties in Western Europe Make Hard Decisions, Cambridge: Cambridge University Press.

Nadeau, R. and A. Blais (1993), 'Accepting the Election Outcome: The Effect of Participation on Loser's Consent', British Journal of Political Science 23(4): 553-563.

Newton, K. (1999), 'Social and Political Trust', in P. Norris (ed), Critical Citizens: Global Support for Democratic Government, Oxford: Oxford University Press.

Newton, K. and P. Norris (2000), 'Confidence in Public Institutions: Faith, Culture, or Performance?', in S.J. Pharr and R.D. Putnam (eds), Disaffected Democracies: What's Troubling the Trilateral Countries? Princeton, NJ: Princeton University Press, pp. 52-73.

Norris, P. (ed) (1999), Critical Citizens: Global Support for Democratic Government, Oxford: Oxford University Press.

Norris, P. (2005), Radical Right: Voters and Parties in the Electoral Market. New York: Cambridge University Press.

Orren, G. (1997), 'Fall from Grace: The Public's Loss of Faith in Government', in J.S. Nye, Jr., P.D. Zelikow and D.C. King (eds), Why People Don't Trust Government? Cambridge, MA: Harvard University Press, pp. 77-107.

Paskeviciute, A. (2006), 'Elections, Policy Representation, and System Legitimacy in Contemporary Democracies', paper presented at the annual meeting of the American Political Science Association, Philadelphia, PA.

Paskeviciute, A. (2009), 'Party Identification and System Support in Contemporary Democracies', in J. Bartle and P. Bellucci (eds), Political Parties and Partisanship: Social Identities and Individual Attitudes, London: Routledge.

Pharr, J. S. and R.D. Putnam (2000), Disaffected Democracies: What's Troubling The Trilateral Countries? Princeton: Princeton University Press.

Powell, G.B. (1982), Contemporary Democracies: Participation, Stability and Violence, Cambridge, MA: Harvard University Press.

Powell, G.B. (1986), 'Extremist Parties and Political Turmoil: Two Puzzles', American Journal of Political Science 30(2): 357-378.

Przeworski, A. (2005), 'Democracy as an Equilibrium', Public Choice 123(3-4): 253-273.

Robertson, D. (1976), A Theory of Party Competition, London and New York: Wiley.

Sanders, D., J. Burton and J. Kneeshaw (2002), 'Identifying the True Party Identifiers: A Question Wording Experiment', Party Politics 8(2): 193-205.

Schattschneider, E.E. (1942), Party Government, New York: Holt, Rinehart, Winston.

Schattschneider, E.E. (1960), The Semi-Sovereign People: A Realist's View of Democracy in America, New York: Holt, Rinehart, Winston. 
Sniderman, P.M. and L. Hagendoorn (2007), When Ways of Life Collide: Multiculturalism and Its Discontents in the Netherlands, Princeton: Princeton University Press.

Stokes, D. (1963), 'Spatial Models of Party Competition', American Political Science Review 57(2): 368-377.

Strøm, K. (1990), 'A Behavioral Theory of Competitive Parties', American Journal of Political Science 34(2): 565-98.

Sullivan, J.L., P. Walsh, M. Shamir, D.G. Barnum and J.L. Gibson (1993), 'Why Politicians are More Tolerant: Selective Recruitment and Socialization among Political Elites in Britain, Israel, New Zealand, and the United States', British Journal of Political Science 23(1): 51-76.

Torcal, M., R.Gunther and J. Ramon Montero (2002), 'Anti-Party Sentiments in Southern Europe', in R. Gunther, J. Ramon Montero and J.J. Linz (eds), Political Parties: Old Concepts and New Challenges, Oxford: Oxford University Press, pp. 257-291.

Tyler, T.R. (1990), Why People Obey the Law, New Haven, CT: Yale University Press.

Volkens, A. (2007), 'Strengths and Weaknesses of Approaches to Measuring Policy Positions of Parties', Electoral Studies 26(1): 108-120.

Volkens, A., J. Bara and I. Budge (2009), 'Data Quality in Content Analysis: The Case of the Comparative Manifestos Project', Historical Social Research - Historische Sozialforschug 34(1): 234-251.

Weingast, B.R. (1997), 'The Political Foundations of Democracy and the Rule of Law', American Political Science Review 91(2): 245-263.

Wolinetz, S.B. (2002), 'Beyond the Catch-All Party: Approaches to the Study of Parties and Party Organization in Contemporary Democracies,' in R. Gunther, J. Ramon Montero and J.J. Linz (eds), Political Parties: Old Concepts and New Challenges. Oxford: Oxford University Press, pp. 136-166.

Zaller, J. (2002), The Nature and Origins of Mass Opinion, New York: Cambridge University Press. 
Table 1. Party Office Orientation by Party Family.

\begin{tabular}{lccccc} 
Party family & N & Mean & SD & Min & Max \\
\hline Green & 6 & 7.157 & 2.279 & 4.75 & 10 \\
Communist & 12 & 7.662 & 2.869 & 2 & 11 \\
Extreme Right & 8 & 9.059 & 3.791 & 1 & 14 \\
Ethnic & 19 & 9.477 & 1.921 & 5.5 & 13 \\
National & 1 & 10 & - & 10 & 10 \\
Liberal & 14 & 12.154 & 2.989 & 6.33 & 16.68 \\
Christian Democrat & 10 & 12.393 & 2.208 & 7.91 & 14.77 \\
Social Democrat & 26 & 12.768 & 2.418 & 7.5 & 16.83 \\
Conservative & 16 & 13.569 & 2.177 & 9.86 & 16.59 \\
Agrarian & 4 & 13.645 & 2.603 & 10.47 & 16.11 \\
\hline Total & $\mathbf{1 1 6}$ & $\mathbf{1 1 . 1 6 5}$ & $\mathbf{3 . 2 6 8}$ & $\mathbf{1}$ & $\mathbf{1 6 . 8 3}$ \\
\hline
\end{tabular}

Table 2. Party Position towards the Constitutional Status Quo by Party Family.

\begin{tabular}{lccccc} 
Party family & N & Mean & SD & Min & Max \\
\hline Ethnic & 19 & -0.511 & 2.538 & -10.606 & 2.768 \\
National & 1 & 0 & - & 0 & 0 \\
Agrarian & 4 & 0 & 0 & 0 & 0 \\
Christian Democrat & 10 & 0.099 & 0.312 & 0 & 0.987 \\
Social Democrat & 26 & 0.136 & 0.41 & -0.57 & 1.153 \\
Green & 6 & 0.178 & 0.373 & 0 & 0.937 \\
Communist & 12 & 0.194 & 0.381 & -0.207 & 0.971 \\
Extreme Right & 8 & 0.215 & 0.502 & 0 & 1.431 \\
Conservative & 16 & 0.518 & 0.953 & -0.507 & 3.229 \\
Liberal & 14 & 0.581 & 1.771 & -0.201 & 6.69 \\
\hline Total & $\mathbf{1 1 6}$ & $\mathbf{0 . 1 4 1}$ & $\mathbf{1 . 2 9 5}$ & $\mathbf{- 1 0 . 6 0 6}$ & $\mathbf{6 . 6 9}$ \\
\hline
\end{tabular}


Table 3. Predicting Party Support for Constitutional Status Quo in 15 Democracies.

\begin{tabular}{lc}
\hline Independent variables & $\begin{array}{c}\text { Party Position towards the } \\
\text { Constitutional Status Quo }\end{array}$ \\
\hline Party office orientation & $.221^{* * *}$ \\
& $.017)$ \\
Party seat-vote disproportionality & $.048^{* * *}$ \\
& $.003)$ \\
Included exogenous individual-level regressors & Yes \\
Country fixed effects & Yes \\
\hline Number of parties & 116 \\
Partial R-squared for excluded instruments & .139 \\
F-statistic for test of excluded instruments & 384.35 \\
F p-value & .000 \\
\hline Note: The results are 2SLS first-stage coefficient estimates (using Stata's ivreg2 \\
command) and their robust standard errors (in parentheses): *p $<.05, * * \mathrm{p}<.01$, \\
$* * * \mathrm{p}<.001$.
\end{tabular}


Table 4. Predicting Citizen Support for Political System in 15 Democracies, 1996-2002.

\begin{tabular}{|c|c|c|c|c|c|c|c|c|}
\hline \multirow{3}{*}{$\begin{array}{l}\text { Independent } \\
\text { variables } \\
\text { Party position towards } \\
\text { the constitutional } \\
\text { status quo } \\
\text { (instrumented) }\end{array}$} & \multicolumn{4}{|c|}{ All Respondents } & \multicolumn{4}{|c|}{ Partisans Only } \\
\hline & \multicolumn{2}{|c|}{$\begin{array}{l}\text { Democracy } \\
\text { Satisfaction }\end{array}$} & \multicolumn{2}{|c|}{$\begin{array}{l}\text { External } \\
\text { Efficacy }\end{array}$} & \multicolumn{2}{|c|}{$\begin{array}{l}\text { Democracy } \\
\text { Satisfaction }\end{array}$} & \multicolumn{2}{|c|}{$\begin{array}{l}\text { External } \\
\text { Efficacy }\end{array}$} \\
\hline & $.160 * * *$ & $(.017)$ & $.301^{* * *}$ & $(.042)$ & $.166^{* * *}$ & $(.016)$ & $.293 * * *$ & $(.038)$ \\
\hline Party identification & .027 & $(.024)$ & $.174 * *$ & $(.059)$ & - & & - & \\
\hline $\begin{array}{l}\text { Left-right self- } \\
\text { placement }\end{array}$ & $.019 * * *$ & $(.002)$ & $.021 * * *$ & $(.006)$ & $.018^{* * *}$ & $(.003)$ & .008 & $(.008)$ \\
\hline $\begin{array}{l}\text { Individual left-right } \\
\text { extremism }\end{array}$ & $-.011 * *$ & $(.004)$ & $.037 * * *$ & $(.010)$ & -.003 & $(.005)$ & $.070 * * *$ & $(.013)$ \\
\hline Economic evaluations & $.147 * * *$ & $(.008)$ & $.356^{* * *}$ & $(.019)$ & $.125^{* * *}$ & $(.010)$ & $.334^{* * *}$ & $(.025)$ \\
\hline Male & $.024 *$ & $(.010)$ & .014 & $(.025)$ & $.039 * *$ & $(.013)$ & .035 & $(.034)$ \\
\hline Age & $-.005 * *$ & $(.00$ & $-.026 * * *$ & $(.0$ & -.003 & $(.0$ & $-.022 * * *$ & $(.007)$ \\
\hline Age squared & $.000 * *$ & $(.000)$ & $.000 * * *$ & $(.00$ & .000 & $(.000)$ & $.000 * *$ & $(.000)$ \\
\hline Educa & $.011 * * *$ & $(.003)$ & $.099^{* * *}$ & $(.008)$ & .008 & $(.004)$ & $.098^{* * *}$ & $(.011)$ \\
\hline Unemployed & $-.097 * * *$ & $(.028)$ & -.017 & $(.071)$ & -.017 & $(.040)$ & .063 & $(.102)$ \\
\hline Married & .012 & $(.012)$ & -.001 & $(.030)$ & .022 & $(.016)$ & .019 & $(.041)$ \\
\hline Income & $.036^{* * *}$ & $(.004)$ & $.067^{* * *}$ & $(.011)$ & $.024 * * *$ & $(.006)$ & $.057 * * *$ & $(.015)$ \\
\hline Party in government & $.106^{* * *}$ & $(.018)$ & $.269^{* * *}$ & $(.044)$ & $.094 * * *$ & $(.018)$ & $.254 * * *$ & $(.045)$ \\
\hline Party legislative size & -.001 & $(.001)$ & .001 & $(.002)$ & -.000 & $(.001)$ & .002 & $(.002)$ \\
\hline $\begin{array}{l}\text { Party left-right } \\
\text { extremism }\end{array}$ & .000 & $(.001)$ & $.006 * *$ & $(.002)$ & .000 & $(.001)$ & $.006 * *$ & $(.002)$ \\
\hline Country fixed effects & \multicolumn{2}{|c|}{ Yes } & \multicolumn{2}{|c|}{ Yes } & \multicolumn{2}{|c|}{ Yes } & \multicolumn{2}{|c|}{ Yes } \\
\hline Constant & $392 * * *$ & $(.052)$ & $2.608 * * *$ & $(.132)$ & $1.445 * * *$ & $(.073)$ & $2.633 * * *$ & $(.186)$ \\
\hline $\begin{array}{l}\text { Number of } \\
\text { observations }\end{array}$ & \multicolumn{2}{|c|}{21,078} & \multicolumn{2}{|c|}{20,885} & \multicolumn{2}{|c|}{11,530} & \multicolumn{2}{|c|}{11,437} \\
\hline $\begin{array}{l}\text { Underidentification } \\
\text { test (Kleibergen-Paap } \\
\text { rk LM statistic) }\end{array}$ & \multicolumn{2}{|c|}{$519.4 * * *$} & \multicolumn{2}{|c|}{$514.2 * * *$} & \multicolumn{2}{|c|}{$614.7 * * *$} & \multicolumn{2}{|c|}{$609.0 * * *$} \\
\hline Hansen J-statistic & \multicolumn{2}{|c|}{.145} & \multicolumn{2}{|c|}{2.543} & \multicolumn{2}{|c|}{.059} & \multicolumn{2}{|c|}{2.271} \\
\hline$X^{2}(1) p$-value & \multicolumn{2}{|c|}{.703} & \multicolumn{2}{|c|}{.111} & \multicolumn{2}{|c|}{.808} & \multicolumn{2}{|c|}{.132} \\
\hline
\end{tabular}

Note: The results are 2SLS second-stage coefficient estimates (using Stata's ivreg2 command) and their robust standard errors (in parentheses): $*_{\mathrm{p}}<.05, * * \mathrm{p}<.01, * * * \mathrm{p}<.001$. Party position towards the constitutional status quo is instrumented using party office orientation and party seat-vote disproportionality. 
Figure1. Party Support for Constitutional Status Quo and Party Goals in 15 Established Democracies.

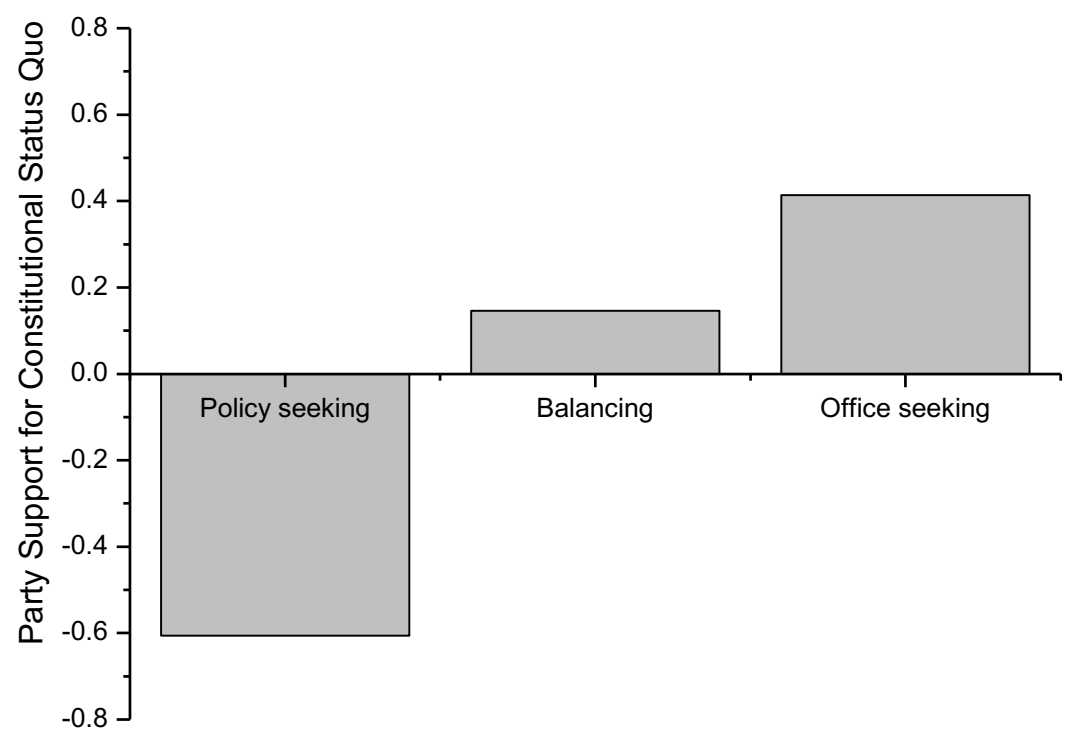

Figure 2. Political System Support among Nonpartisans and Partisans of Parties with High, Medium, and Low Support for the Constitutional Status Quo in 15 Established Democracies.

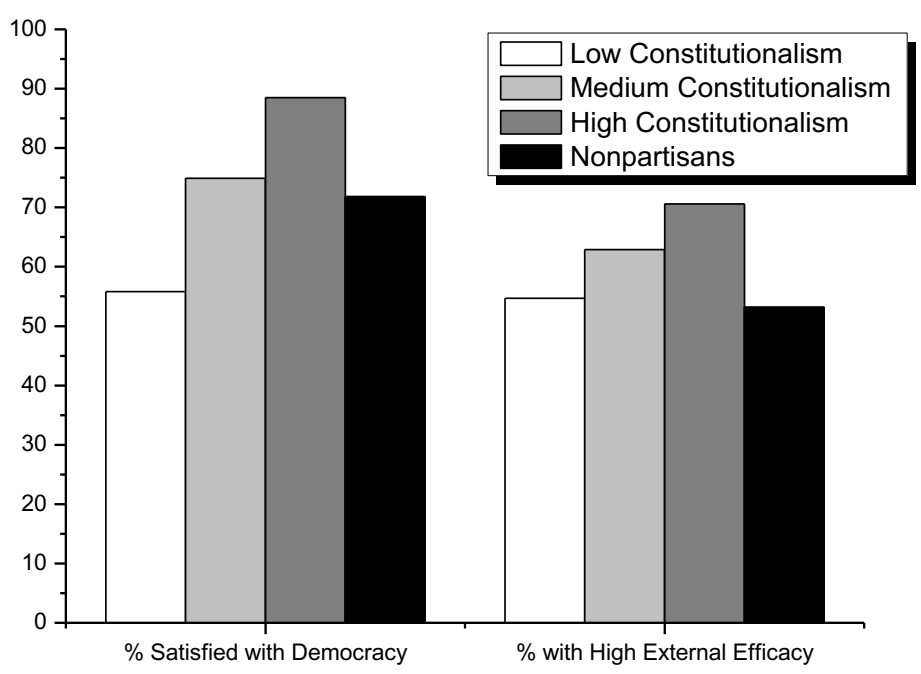


Figure 3a. The Effects of Party Positions towards Constitutional Status Quo on Partisans' Satisfaction with Democracy in 15 Democracies, 1996-2002.

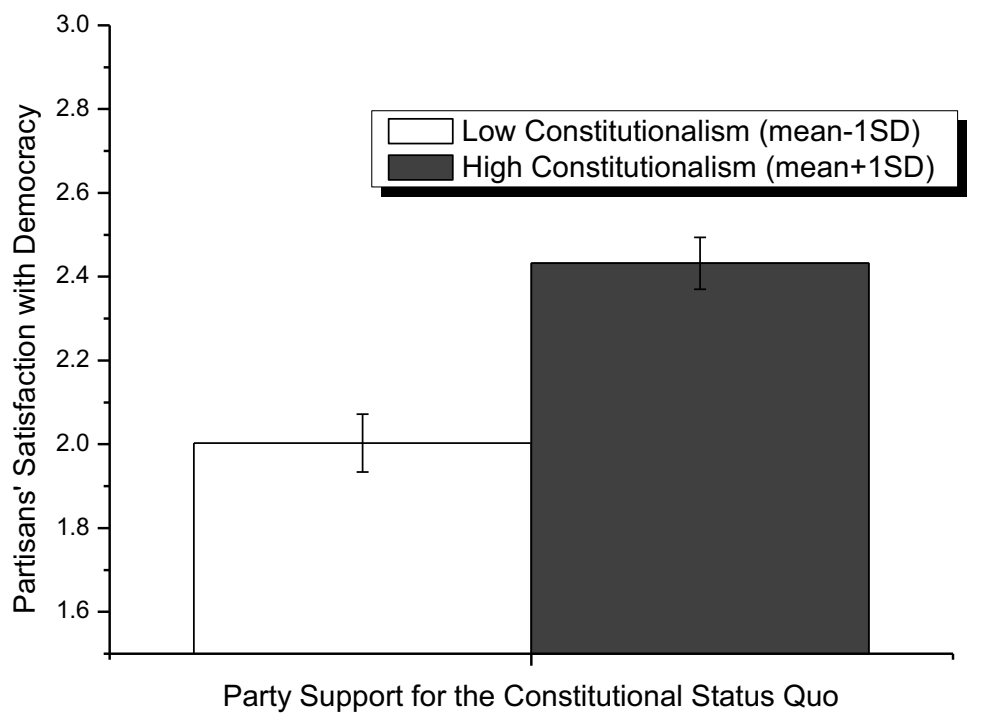

Note: Vertical lines indicate $95 \%$ confidence intervals

Figure 3b. The Effects of Party Positions towards Constitutional Status Quo on Partisans' External Efficacy in 15 Democracies, 1996-2002.

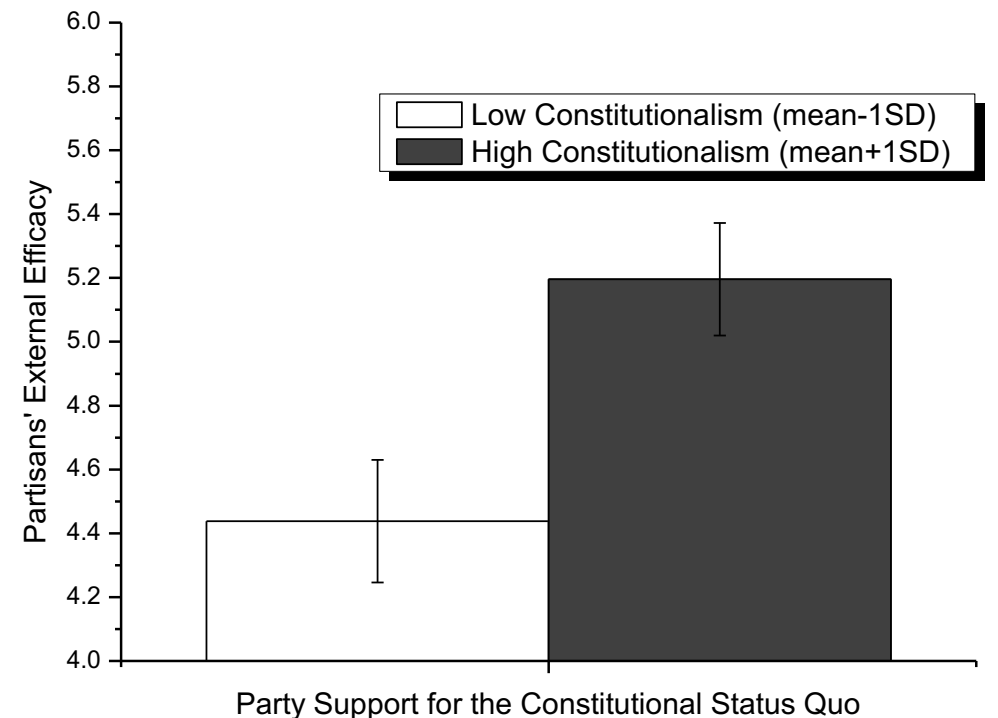

Note: Vertical lines indicate $95 \%$ confidence intervals 